\title{
G-quartet-dependent recognition between the FMRP RGG box and RNA
}

\author{
ANDRES RAMOS, DAVID HOLLINGWORTH, and ANNALISA PASTORE
}

National Institute for Medical Research, London NW7 1AA, UK

\begin{abstract}
Fragile-X syndrome, the most common monogenic form of mental retardation, is caused by down-regulation of the expression of Fragile X Mental Retardation Protein (FMRP). FMRP is a multifunctional, multidomain RNA-binding protein that acts as a translational repressor in neuronal cells. Interaction between FMRP and mRNA targets involves an RGG box, a protein motif commonly thought to mediate unspecific interactions with nucleic acids. Instead, FMRP RGG box has been shown to recognize RNA G-quartet structures specifically and to be necessary in neurons for RNP particle formation and dendritic mRNA localization. In the present study, we have characterized structurally three representative RNA targets of FMRP in their unbound form and in complex with the RGG box. We observe a large heterogeneity in the conformation of the RNA targets and in their RGG binding mode, which could be the basis of recognition specificity. We also found that G-quartet formation occurs not only intramolecularly but can also be mediated by RNA dimerization. These findings suggest a potential role of RNA:RNA interactions in protein:RNA complexes and in RNP particle assembly.
\end{abstract}

Keywords: Fragile X; NMR; RNA-binding proteins; structure

\section{INTRODUCTION}

Fragile X syndrome-the most common form of inherited mental retardation - is a dominant defect associated with anomalous expansion of a CGG triplet near the promoter of the Fragile X Mental Retardation 1 (FMR1) gene, leading to gene silencing (Bardoni and Mandel 2002). The gene product, Fragile X Mental Retardation Protein (FMRP), is a predominantly cytoplasmic RNA-binding protein expressed in many tissues and particularly abundant in neurons. It seems to perform multiple regulatory functions in diverse posttranscriptional regulatory processes (Ishizuka et al. 2002; Zalfa et al. 2003). In neuronal cells, FMRP has been associated with the assembly of ribonucleoproteins (RNPs), large particles containing RNAs and proteins (Corbin et al. 1997; Feng et al. 1997; Mazroui et al. 2002), and to their microtubule-linked migration along the dendritic axis (De Diego Otero et al. 2002). FMRP interacts directly with several mRNAs (Brown et al. 2001; Darnell et al. 2001; Schaeffer et al. 2001), with the nontranslatable BC1 RNA (Zalfa et

Reprint requests to: Annalisa Pastore, National Institute for Medical Research, Division of Molecular Structure, The Ridgeway, Mill Hill, London NW7 1AA, UK; e-mail: apastor@nimr.mrc.ac.uk.

Article and publication are at http://www.rnajournal.org/cgi/doi/ 10.1261/rna.5960503. al. 2003), and with ribosomes (Siomi et al. 1996; Corbin et al. 1997), and it has recently been associated with RNA interference (Ishizuka et al. 2002). Several cytoplasmic and nuclear protein partners of FMRP that could assist some FMRP functions have also been identified (Ceman et al. 1999, 2000; Mazroui et al. 2002; Ohashi et al. 2002; for review, see Bardoni and Mandel 2002). Microarray studies have shown that several mRNAs are up-regulated in FMR1 knockout mice, thus suggesting that FMRP is a translational repressor involved in the development of neurons (Laggerbauer et al. 2001; Li et al. 2001; Mazroui et al. 2002).

FMRP contains at least four RNA-binding motifs (Fig. 1A): a novel NDF motif at the $\mathrm{N}$ terminus, two $\mathrm{KH}$ domains, and an RGG box near the C-terminal end (Adinolfi et al. 1999, 2003). Although the information available so far strongly indicates that other regions of FMRP might independently be implicated in RNA recognition, the RGG box seems to be a "hotspot" for FMRP:RNA interaction. FMRP interactions with mRNAs have, in fact, all been mapped onto the RGG box, which is sufficient for binding in vitro (Darnell et al. 2001) and necessary for the assembly of the RNP complex (Mazroui et al. 2002). Analysis of the mRNA target sequences has shown a preference for G-rich sequences that bind to FMRP in a potassium-dependent manner, suggesting that the protein binds to G-quartet motifs 


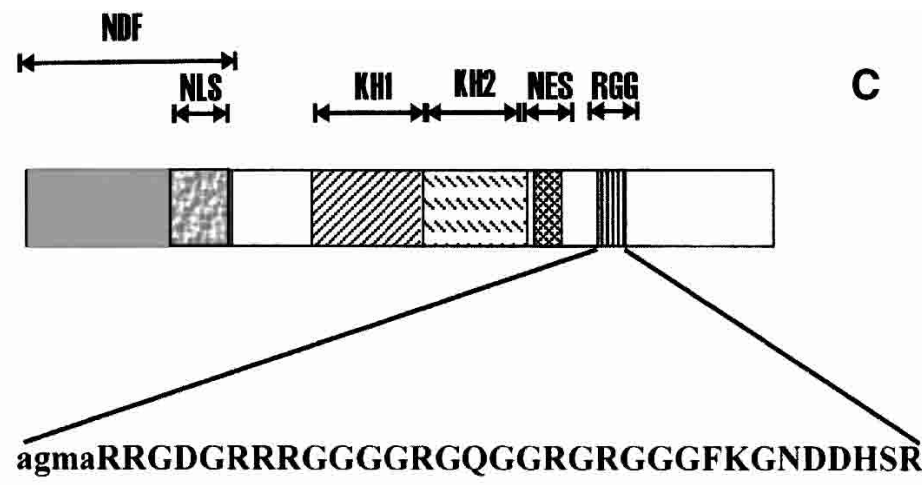

A

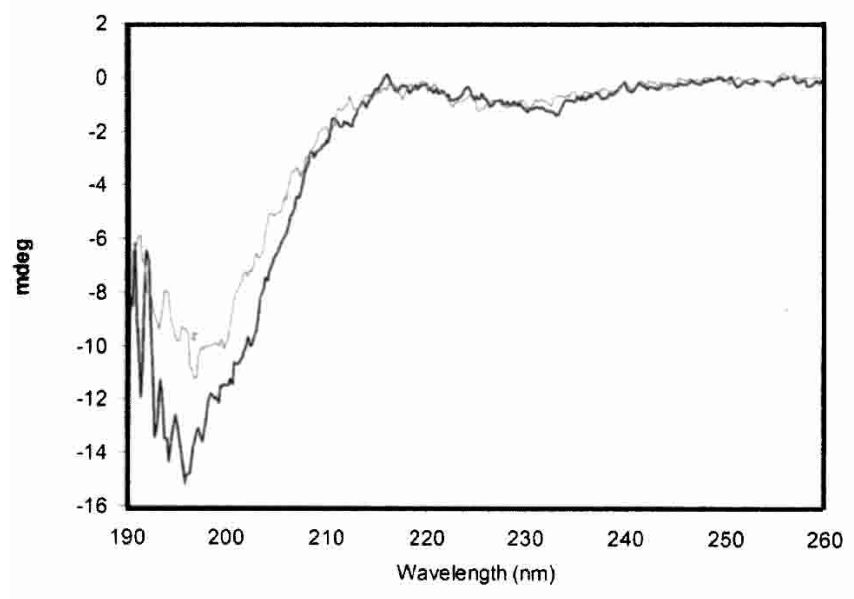

B
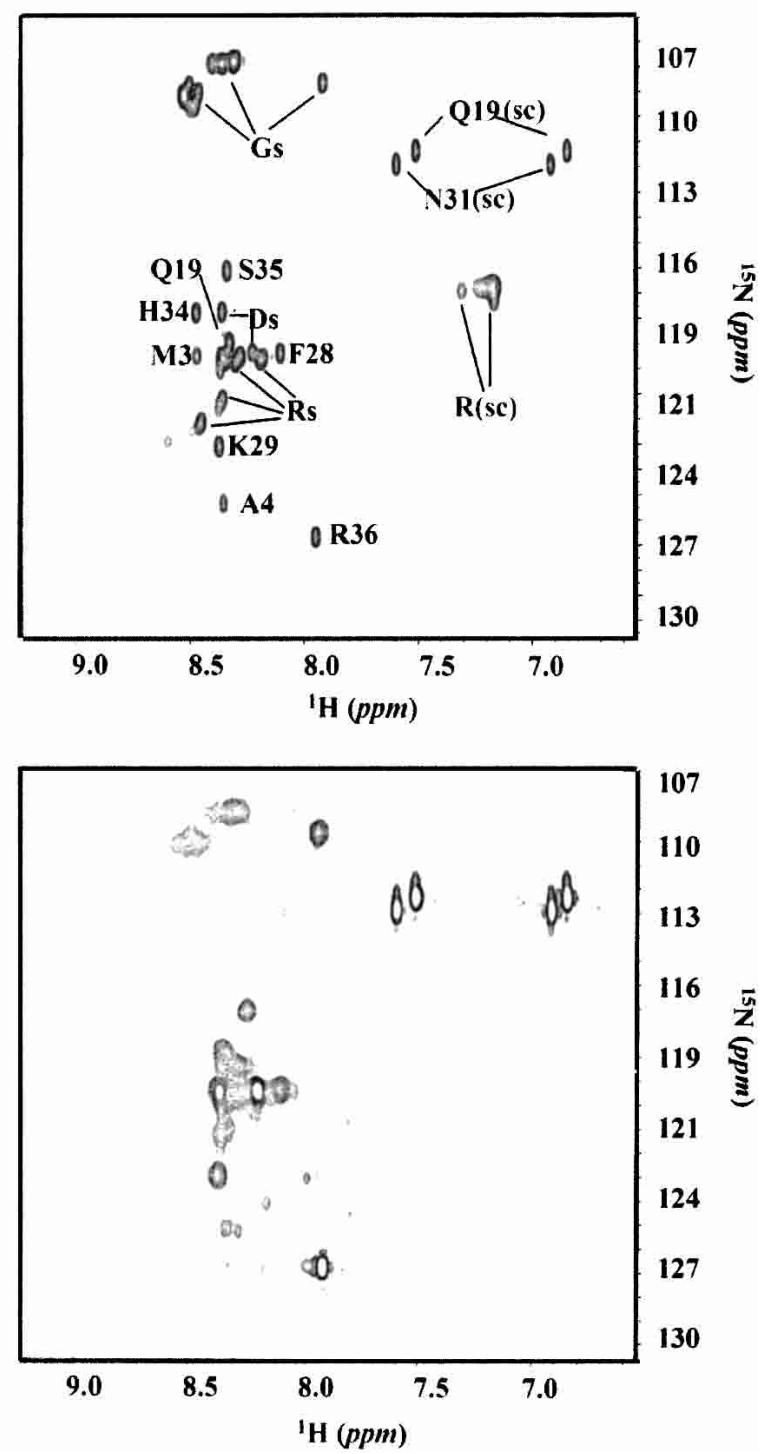

FIGURE 1. (A) FMRP domain structure. The different motifs are indicated: NDF, NLS, NES, KH1 and KH2, and RGG stand for the N-terminal domain of FMRP, the nuclear localization signal, the nuclear export signal, the two K-homology (KH) domains, and the RGG motif, respectively. The sequence of RGG_P is shown in the inset. Four additional residues (in lower case) were added for cloning and purification purposes. (B) Far-UV CD spectra of RGG_P at pH 5 (black curve) and pH 7 (gray curve) and $20^{\circ} \mathrm{C}$. (C) ${ }^{1} \mathrm{H}_{-}{ }^{15} \mathrm{~N}$ HSQC spectra of the peptide at pH 5 (top) and $7.4\left(\right.$ bottom). The spectra were recorded at $27^{\circ} \mathrm{C}$ using a $1.3-\mathrm{mM}$ concentration of RGG_P. Partial assignment of the peptide resonances is indicated. The sidechain exchangeable protons of Arg, Gln, and Asn are indicated by (sc).

(Darnell et al. 2001; Schaeffer et al. 2001). G-quartets are nucleic acid structures in which four guanine residues are arranged in a planar conformation stabilized by Hoogsteentype hydrogen bonds (Keniry 2001). Several such planar structures can stack and be further stabilized by potassium or sodium cations, whereas they are destabilized by lithium cations. This structural motif seems to be relatively common, as more than 80 potential mRNA partners that interact with FMRP in a potassium-dependent manner have been identified in neurons (Miyashiro et al. 2003). If, however, the same region of FMRP is able to recognize Gquartet structures from different mRNAs, an important question is whether the protein regulates all of these RNAs or only a subset of them and how specificity may be achieved. Because no structural information is currently available about RGG boxes, probably due to the inherent flexibility of this motif, and very little is known about Gquartet:protein interactions, it is difficult to find a straightforward answer to these questions.

We set out to explore the conformation of representative FMRP RNA targets and to characterize their mode of binding to the FMRP RGG box using complementary biophysical and biochemical techniques. Among these, we used nuclear magnetic resonance (NMR) to probe RNA struc- 
tures and to extract the essential features of systems that, because of their intrinsic flexibility, are difficult to study at high resolution. Comparison of the results obtained for three FMRP targets provides new insights into general features of the FMRP-RNA interaction.

\section{RESULTS AND DISCUSSION}

\section{A 32 amino acid peptide containing the RGG box is unstructured and flexible}

A recombinant peptide (RGG_P) spanning residues 527558 of FMRP and containing the RGG box was expressed and purified (Fig. 1A). This sequence is sufficient for in vitro binding of several FMRP mRNA targets (Darnell et al. 2001). The structure of the peptide was probed by circular dichroism (CD) and NMR techniques (Fig. 1B,C). The farUV CD spectrum of the peptide is typical of a random coil conformation with a single minimum at wavelengths shorter than $200 \mathrm{~nm}$. A flexible random conformation is also confirmed by the slow relaxation and the random coil chemical shifts of the peptide resonances, by the absence of interresidue NOESY connectivities, and by broadening of the peaks at $\mathrm{pH} 7.4$.

We therefore confirm experimentally that the region of FMRP that contains the RGG box is flexible and unstructured, as suggested by its low-complexity sequence composition (44\% glycines and $28 \%$ arginines).

\section{Representative RNA sequences were selected to characterize the RGG_P:RNA interaction}

We selected three RNAs as representatives of the RGG_P: RNA interactions: the FMRP and the microtubule associated protein 1B (MAP1B) mRNAs and the SELEX-derived SC1 RNA. Both mRNAs were selected because of their potential functional importance. Interactions between FMRP and its mRNA could self-regulate the protein expression. MAP1B mRNA co-immunoprecipitates with FMRP, and the expression of MAP1B, a protein involved in cytoskeleton-dependent transport (Müller et al. 1994), is FMRP dependent (Brown et al. 2001). A dendritic morphology associated with the Fragile $\mathrm{X}$ syndrome has been linked to FMRP-dependent down-regulation of MAP1B (Zhang et al. 2001), providing a phenotypic marker for the FMRP:MAP1B mRNA interaction. SC1 is, among the SELEX-derived RNAs, the one with highest affinity (Darnell et al. 2001).

Three oligonucleotides (hereafter indicated as FMRP_RNA, MAP1B_RNA, and SC1_RNA) were designed to include the putative RGG-binding regions of these RNAs. Their sequences are reported in Figure 2A, together with predictions of their secondary structures (Zucker 2003). A fourth, G-rich RNA (MUNC_RNA), derived from site 1 of MUNC mRNA and known to bind to FMRP with low affinity (Dar- nell et al. 2001), was used as a negative control (sequence not shown).

\section{The selected RNAs form G-quartets with distinct features}

The conformation of the RNAs was probed by NMR, native gel-shift assays, and analytical ultracentrifugation in the presence of $\mathrm{Li}^{+}$or $\mathrm{K}^{+}$ions, which, respectively, destabilize and promote formation of G-quartet structures (Hardin et al. 2001).

RNA secondary structure can be monitored by one-dimensional (1D) ${ }^{1} \mathrm{H}$ NMR from the appearance of guanosine imino resonances in the region $10 \mathrm{ppm}$ to $12 \mathrm{ppm}$ mostly diagnostic for G-quartets and in the region $12 \mathrm{ppm}$ to 14 ppm typical of Watson-Crick base pairing. The spectra of the control MUNC_RNA with both $\mathrm{Li}^{+}$and $\mathrm{K}^{+}$show that this RNA is unable to form stable G-quartets (data not shown). Comparison of the spectra of the other three RNAs in $\mathrm{LiCl}$ and in $\mathrm{KCl}$ clearly indicates formation, under physiological conditions, of G-quartets (Fig. 2B). However, the sequence context determines large differences in the folds and stabilities of the three molecules. FMRP_RNA is the most selective of the three RNAs, as, in the presence of $\mathrm{K}^{+}$, the only detectable stable structures are G-quartets, suggesting that the two predicted short base-paired regions (Fig. 2A) that form with $\mathrm{Li}^{+}$are either very unstable or mutually inconsistent with G-quartet formation. MAP1B_RNA, whose spectrum in the presence of $\mathrm{Li}^{+}$indicates the presence of Watson-Crick type structures only, appears to contain both Watson-Crick and G-quartet structures with $\mathrm{K}^{+}$. $\mathrm{SC}_{1} \mathrm{RNA}^{+}$has a similar behavior but seems to retain upfield imino resonances also with $\mathrm{Li}^{+}$.

An ion-dependent conformational change was also observed in native gels (Fig. 3A). FMRP_RNA and MAP1B_RNA migrate as single species both with $\mathrm{Li}^{+}$and $\mathrm{K}^{+}$, although the broader appearance of the bands in $\mathrm{Li}^{+}$ suggests the presence of multiple conformations. Two distinct relatively stable forms of SC1_RNA coexist with approximately similar populations. FMRP_RNA has increased mobility with $\mathrm{K}^{+}$compared to $\mathrm{Li}^{+}$, whereas, unexpectedly, MAP1B_RNA decreases its mobility. A key to understanding these findings was provided by equilibrium analytical ultracentrifugation measurements (Fig. 3B). The experimental data for FMRP_RNA can be fitted with high accuracy assuming a monomeric species both with $\mathrm{Li}^{+}$and $\mathrm{K}^{+}$. Fitting of the curves recorded for MAP1B_RNA requires the assumption that the RNA is mainly monomeric with $\mathrm{Li}^{+}$ $(80 \%)$, where the only stable structure is Watson-Crick base pairing, but dimeric with $\mathrm{K}^{+}$. This $\mathrm{K}^{+}$-dependent monomer-dimer transition suggests an intermolecular Gquartet formation. The observed decrease of mobility of MAP1B_RNA in the native gel assay can therefore be explained by $\mathrm{K}^{+}$-dependent dimerization of this RNA. Two distinct populations of SC1_RNA in mutual equilibrium, 


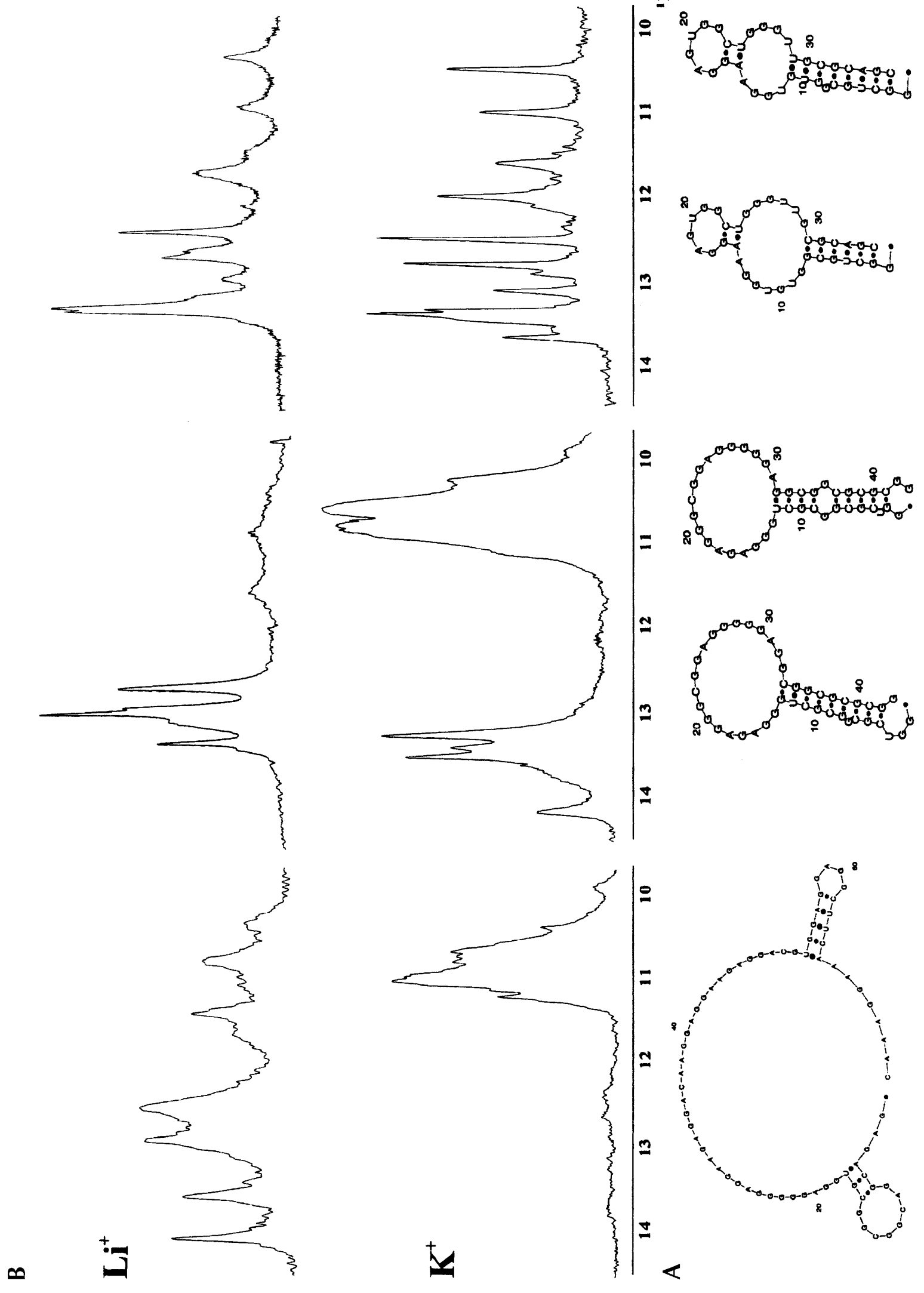



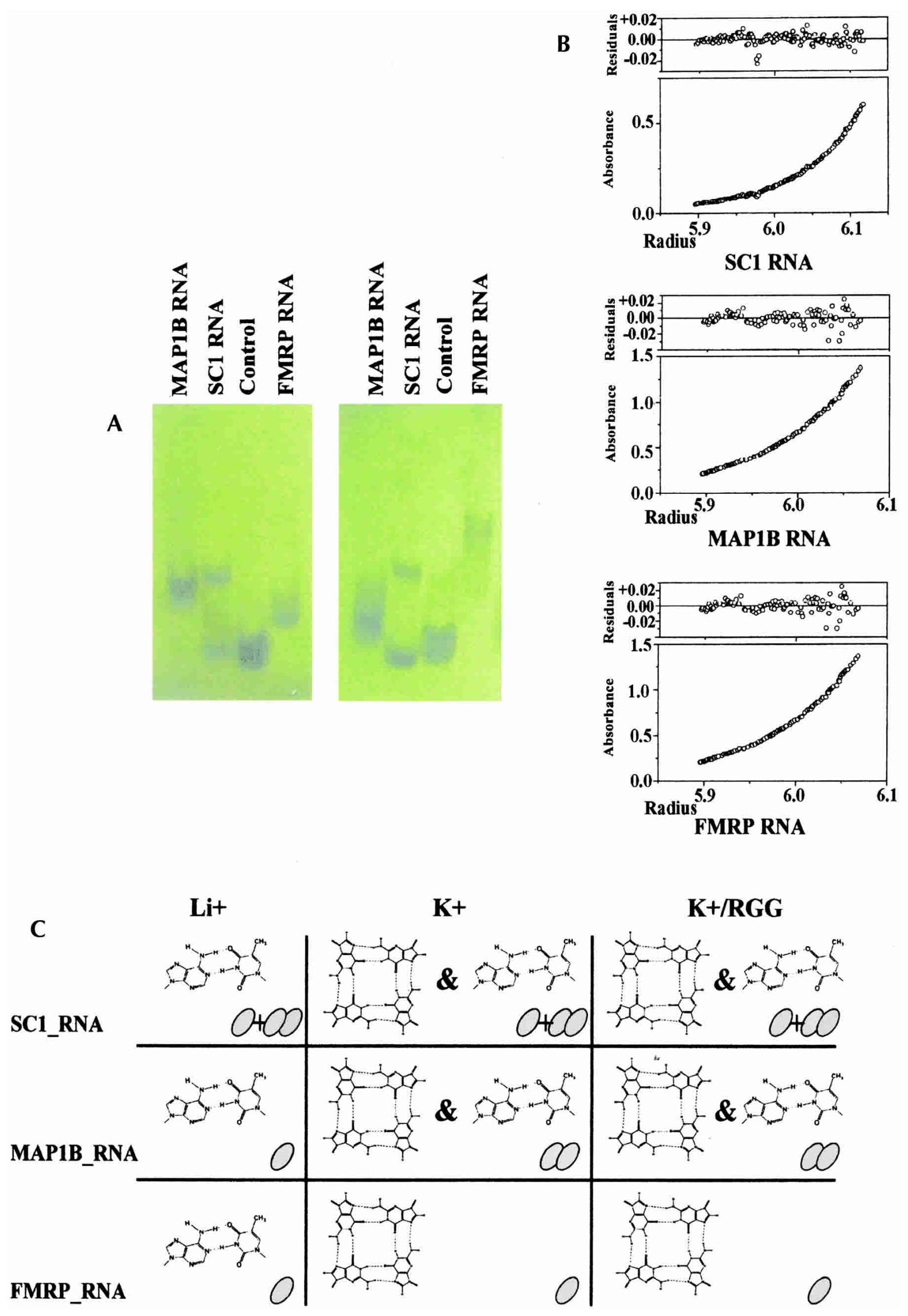

FIGURE 3. (Legend on facing page) 
one monomeric, the other dimeric, are present in equimolar ratio. The relative concentration was not affected by $\mathrm{Li}^{+}$or $\mathrm{K}^{+}$.

In summary, our results point to a large diversity both in the conformations and in the multimeric state adopted by the FMRP RNA targets despite the common capability of forming G-quartets (Fig. 3C).

\section{The RNA context determines the affinity of recognition}

Chemical shift and peak intensity variations upon titration of RGG_P with the individual RNAs in $150-\mathrm{mM} \mathrm{KCl}$ or $\mathrm{LiCl}$ solutions were followed by recording ${ }^{1} \mathrm{H}-{ }^{15} \mathrm{~N}$ HSQC NMR spectra of the ${ }^{15} \mathrm{~N}$-labeled peptide. In all three cases, only minor spectral changes are observed with $\mathrm{LiCl}$, suggesting that, in the absence of G-quartet formation, the interactions between RGG_P and the RNAs are weak and probably unspecific. In $\mathrm{KCl}$, maximal spectral changes are observed for 1:1 protein: RNA ratios in the FMRP_RNA: RGG_P and of the MAP1B_RNA:RGG_P complexes (data not shown). Complete formation of the SC1_RNA:RGG_P complex occurs instead at a ca. 2:1 RNA:peptide ratio (Fig. 4A). This reflects the ca. 1:1 mixture of the monomeric and dimeric species, with only the monomeric one binding to the peptide. Analytical ultracentrifugation confirmed complex formation and the stoichiometry (data not shown).

Using RNA concentrations of $0.12 \mathrm{mM}$ to which RGG_P was added to reach RNA:protein ratios of $1: 1,1: 2$, and $1: 3$, a significant bandshift was observed in native gel electrophoresis for FMRP_RNA and MAP1B_RNA and for the SC1_RNA monomer upon titration with increasing amounts of RGG_P (data not shown). However, the sharpness of the SC1_RNA monomer band and the lower RNA:peptide ratio necessary for saturation suggest that RGG_P binds to SC1_RNA more tightly than to MAP1B_RNA and FMRP_RNA. No shift was observed for the control RNA.

Different binding affinities are reflected also by differences in the exchange regime of the peptide in the three complexes observed by NMR. The RGG_P:FMRP_RNA and RGG_P:MAP1B_RNA complexes are in moderately fast exchange on a chemical shift timescale (data not shown). The RGG_P:SC1_RNA complex is in slow exchange as shown by the appearance of new resonances upon complex formation (Fig. 4A). If we assume that the free:bound exchange rate is significantly slower than $1 \mathrm{kHz}$ and the com- monly accepted approximation that the on-rate of the binding reactions is diffusion limited, a difference in the exchange rate can be linked to differences in the equilibrium constant of the complex. This can be estimated to be in the nanomolar range for RGG_P:SC1_RNA and in the lower micromolar range for the other two complexes.

Therefore, the binding affinities of the three RNAs to RGG_P are remarkably different, like their secondary structures. Binding of RGG_P to the SELEX-derived RNA is approximately two orders of magnitude tighter than it is to the natural targets, in agreement with the values reported in Darnell et al. (2001). The apparent paradox, that in vivo sequences have lower affinity than an in vitro one, may easily be explained by the consideration that, as with other screening methods, SELEX-selected sequences are optimized solutions. They appear to mimic an evolutionary process but do not take into account longer sequence environments. Relatively modest binding constants are often observed for several domains of modular proteins, in which tighter binding affinities and different specificities can be modulated by cooperative contributions of different domains. Suitable examples are the semi-specific structural recognition of RNA double helices by the double-stranded RNA-binding domains (dsRBDs) of Staufen and the multi$\mathrm{KH}$ domain protein NOVA (Buckanovich and Darnell 1997; Ramos et al. 2000b). Low binding affinities could also be required to facilitate reversibility of the RNA interaction with FMRP: Some of the G-quartet-forming sequences (e.g., FMRP mRNA, Mint mRNA) are in the exonic part of the mRNA. Protein detachment and G-quartet disruption might therefore be necessary for translation.

\section{Probing the conformation of the RNAs and of RGG_P in the complex}

Both flexibility and the low affinities involved make full structure determination of the complexes discussed here difficult. However, qualitative observations can help us to describe at least their general features. The conformation of the RNAs with $\mathrm{K}^{+}$upon peptide binding was probed by detecting $1 \mathrm{D}{ }^{1} \mathrm{H}$ NMR experiments at each point of the titration and looking at the spectral region diagnostic for RNA structures. Once again, the three RNAs behave differently (Fig. 4B and last column in Fig. 3C). A comparison of Figures $2 \mathrm{~B}$ and $4 \mathrm{~B}$ indicates that in the spectrum of FMRP_RNA:RGG_P, chemical shifts are observed in the imino protons of G-quartets, the only stable structure pre-

FIGURE 3. (A) Native gel of: MAP1B_RNA (lane 1), SC1_RNA (lane 2), MUNC_RNA (lane 3), and FMRP_RNA (lane 4 ) run using 0.12 mM RNA concentrations in $40 \mathrm{mM}$ Tris-Acetate (pH 7.2) and $100 \mathrm{mM} \mathrm{KCl}($ left $)$ and $100 \mathrm{mM} \mathrm{LiCl}($ right $)$. (B) Fitting of a typical set of analytical ultracentrifugation data recorded for the three RNAs. Sample concentrations were $1 \mu \mathrm{M}$ in $10 \mathrm{mM}$ Tris- $\mathrm{HCl}(\mathrm{pH} 7.4)$ and $150 \mathrm{mM} \mathrm{KCl}$. $(C)$ Summary of the observed secondary structures and multimeric state of the three RNAs studied. Appropriate symbols are used for indicating the presence of G-quartets and Watson-Crick base pairing. Monomers and dimers are indicated with one and two ovals, respectively. Plus and ampersand are used to indicate the coexistence of monomeric and dimeric species in solution and of helical and G-quartet structures. It should, however, be appreciated that the two types of secondary structures can, in principle, be formed intramolecularly or intermolecularly. 

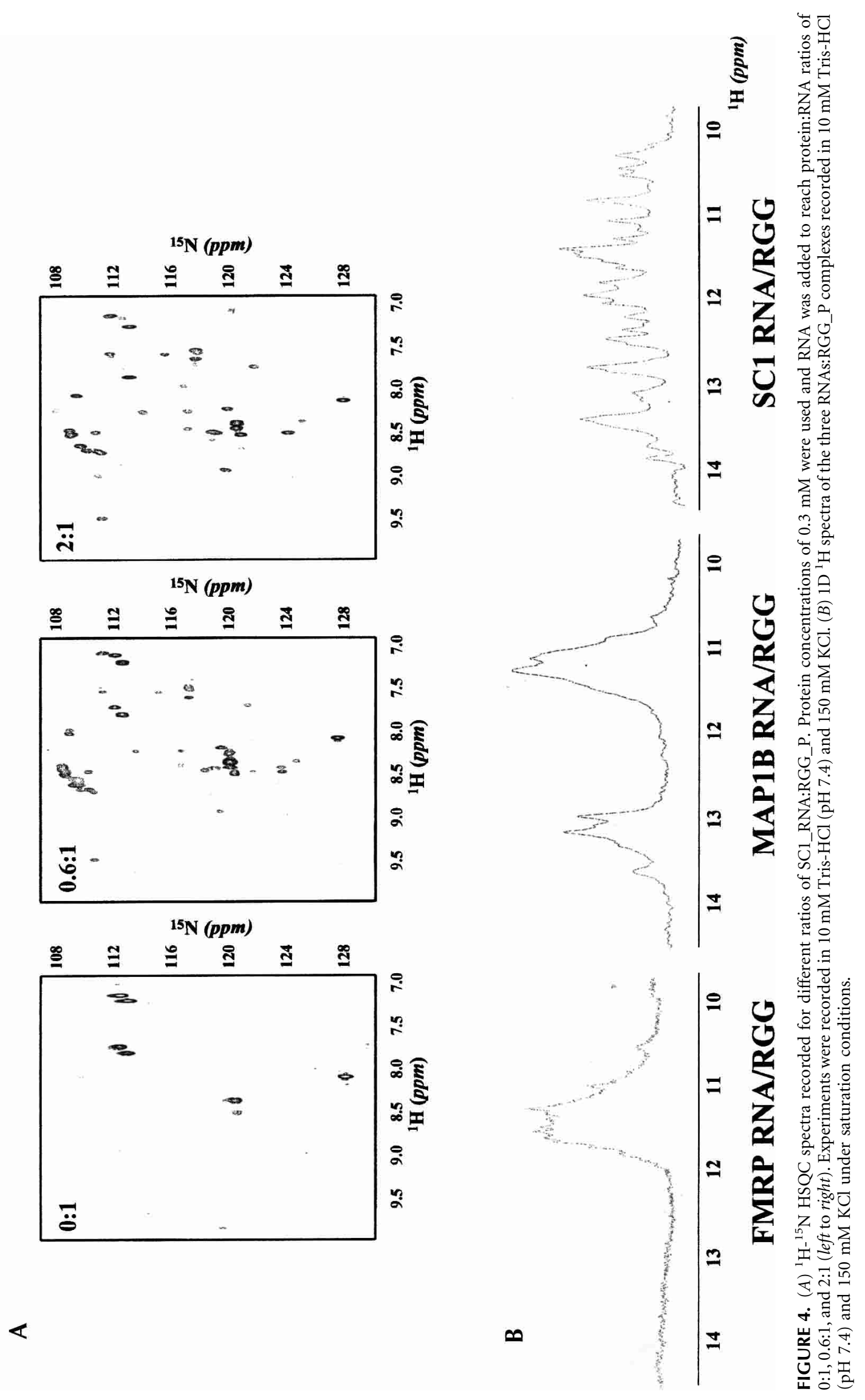
sent with $\mathrm{K}^{+}$. In the MAP1B_RNA:RGG_P complex, no shift is observed in the imino Watson-Crick region of the spectra, whereas changes do occur in the G-quartet region. This indicates that the interacting region with RGG_P is limited to the G-quartet structures. In the spectrum of SC1_RNA:RGG_P, a new set of peaks appears in both the Watson-Crick and G-quartet imino regions upon complex formation, but peaks corresponding to the free RNA resonances remain visible. This observation is consistent with the presence of two SC1 populations (monomer and dimer), only one of which (the monomer) binds to the RNA at these ratios.

Further information about the RGG:RNA interaction was obtained from the NMR spectra of RGG_P in complex with SC1_RNA, which has sufficient affinity to allow such analysis (Figs. 4A, 1C). Partial assignment of the spectrum of free RGG_P and comparison with that of the peptide in the complex suggests that the interaction involves the $\mathrm{N}$ terminus and the middle of the RGG_P sequence: Resonances arising from Phe28, Lys29, Asn31, and Ser35 (easily recognizable because they are unique in the sequence) retain similar chemical shifts in the complex. Several resonances in the chemical shift range typical of glycines (i.e. in the 108$112 \mathrm{ppm}$ range) are shifted or appear de novo. The side chains of arginines and of the unique glutamine (Gln19) are also significantly shifted. An estimate of the surface of interaction was obtained from cross-saturation NMR experiments in which the effect of irradiation of an RNA resonance can be observed on the peptide resonances (Ramos et al. 2000a). Irradiation of the anomeric RNA resonances of SC1_RNA in $\mathrm{K}^{+}$affects seven backbone and five side-chain amide resonances (data not shown). A comparable number of effects was observed in the very tight sequence-specific Nova-1 KH3-RNA complex (Buckanovich and Darnell 1997), in which the protein component is roughly double the size of RGG_P (Ramos et al. 2000). The contacts observed between the arginine side chains and the RNA confirm that these side chains play a major role in protein:RNA interactions.

An induced-fit recognition between the flexible, highly charged RGG and the G-quartets seems an ideal solution to mediate binding of a large number of different mRNA targets to FMRP. However, we show that within the frame of an RGG:G-quartet recognition, both the RNA context and the cation composition dictate a large complexity of conformations and multiplicity states (summarized in Fig. 3C). This complexity could provide the key for specificity among the possible RNA partners. An interesting observation suggested by our results is that G-quartet formation may be mediated by RNA dimerization, which we observe for MAP1B_RNA at micromolar RNA concentration and under physiological $\mathrm{pH}$ and salt concentration. A crucial role of mRNA dimerization has been reported for the formation of specific bicoid mRNA 3' UTR-Staufen ribonucleoprotein particles responsible for mRNA localization and cell differ- entiation in Drosophila (Ferrandon et al. 1997). Self-association of this RNA occurs via a symmetric interaction between two different loops, and is necessary for the functional association with the Staufen protein in Drosophila embryos. Similarly, G-quartet structures, which can form from one, two, or four RNA molecules, could represent an important and flexible motif for mRNA oligomerization necessary for RNP particle formation and posttranscriptional mRNA localization in neurons. Because the RGG box of FMRP is necessary for the formation of RNP particles involved in the localization of a number of mRNAs in specific neuronal compartments (Mazroui et al. 2002), we might speculate that intermolecular RNA:RNA interactions could be involved in this process, for instance, by regulating the number of particles of a specific mRNA present in a given complex.

In conclusion, the study discussed here provides both a first step towards understanding the molecular bases of FMRP:mRNA recognition and, at the same time, a direct indication of the complexity that the interaction between an RGG box and G-quartets may involve.

\section{MATERIALS AND METHODS}

\section{RNA and protein preparation}

RNA oligonucleotides were synthesized in vitro using T7 RNA polymerase and synthetic DNA templates using standard conditions (Price et al. 1995). The ratios of the 4-nt triphosphates was chosen to match the sequences to be transcribed, which are guanosine rich. The RNA oligos were then purified essentially as described in Price et al. (1995) but using Tris- $\mathrm{HCl}$ buffer with no salt in the intermediate and final dialysis steps. In short, the oligos were purified on a denaturing polyacrylammide gel, electroeluted, and dialyzed overnight against $10 \mathrm{mM}$ Tris- $\mathrm{HCl}$ at $\mathrm{pH}$ 7.4. They were then desalted using a G15 column and further dialyzed against the final buffer. A 36 amino acid peptide was overexpressed as a histidine-tagged GST-fusion protein in Escherichia coli BL21DE3. It comprised amino acids 527-558 of FMRP preceded by four residues added for cloning and purification purposes. The peptide was purified using a two-step protocol. After breaking the cells, the soluble fraction was loaded on a nickel-affinity column. The protein was eluted in $300 \mathrm{mM}$ imidazole and then dialyzed against $10 \mathrm{mM}$ imidazole buffer. RGG_P was cleaved from GST by overnight TEV digestion at $25^{\circ} \mathrm{C}$. The product was loaded on a nickel-affinity column to remove the histidine-tagged TEV and GST. The unbound RGG_P was concentrated and dialyzed against the final buffer. ${ }^{15} \mathrm{~N}$-labeled peptide was obtained by expressing the GST-RGG_P in M9 media supplemented with ${ }^{15} \mathrm{~N} \mathrm{NH}_{4} \mathrm{SO}_{4}$ as the sole nitrogen source. The homogeneity and molecular weight of the peptide were confirmed by electrospray mass spectrometry. As the calculated peptide molar extinction coefficient is very low (200 mole $\mathrm{m}^{-1} \mathrm{~cm}^{-1}$ ), concentrations of the unlabeled and labeled samples were determined using amino acid analysis.

\section{Circular dichroism}

CD measurements were performed on a Jasco J-715 spectropolarimeter. Spectra were recorded at $27^{\circ} \mathrm{C}$ on $0.5-\mathrm{mM}$ samples of 
RGG_P either in $10 \mathrm{mM}$ acetate buffer at $\mathrm{pH} 5$ or in $10 \mathrm{mM}$ Tris- $\mathrm{HCl}$ buffer at $\mathrm{pH} 7$.

\section{Electrophoretical mobility assays}

The RNA oligos were heated at $90^{\circ} \mathrm{C}$ for $5 \mathrm{~min}$ in $20 \mathrm{mM}$ Tris- $\mathrm{Cl}$ at pH 7.2 containing $150 \mathrm{mM} \mathrm{KCl}$ or $\mathrm{LiCl}$, and cooled to $4^{\circ} \mathrm{C}$ over $1 \mathrm{~h}$. The RNA concentration was $0.12 \mathrm{mM}$. RGG_P was added to concentrations of $0.12,0.24$, and $0.36 \mathrm{mM}$. Samples were run at 5 $\mathrm{V} / \mathrm{cm}$ on $10 \%$ acrylamide gels in $40 \mathrm{mM}$ Tris-Acetate at $\mathrm{pH} 7.2$ and $100 \mathrm{mM} \mathrm{KCl}$ or $\mathrm{LiCl}$.

\section{Analytical ultracentrifugation}

Sedimentation equilibrium experiments were carried out using a Beckman XL-A analytical ultracentrifuge equipped with UV absorption optics. Data were recorded at $15^{\circ} \mathrm{C}$ and speeds of 16,000 , 22,000, and 26,000 rpm. Data were recorded twice at each speed with an 8-h gap and a 16-h gap between speeds. Comparison of the two measurements at the same speed confirms that equilibrium has been reached and that the RNA is not degrading. The baseline value was obtained fitting results recorded at different speeds. The concentrations of the different RNAs were between 0.5 and $1 \mu \mathrm{M}$, chosen so that the absorbance at $260 \mathrm{~nm}$ is in the range $0.2-0.8$. The data were analyzed with the Origin XL-A/XL1 package (Beckman) and a two component self-association mechanism was assumed, to allow for dimerization.

\section{NMR}

NMR spectra were recorded at $27^{\circ} \mathrm{C}$ on Varian INOVA and UnityPlus spectrometers operating at 500, 600, and $800 \mathrm{MHz}{ }^{1} \mathrm{H}$ frequencies. 1D ${ }^{1} \mathrm{H}$ experiments and $2 \mathrm{D}{ }^{1} \mathrm{H}-{ }^{1} \mathrm{H}$ NOESY and TOCSY were used for the characterization of peptide and RNA. Mixing times were 50, 100, and $300 \mathrm{~ms}$ for the NOESY and 40, 70, and $100 \mathrm{~ms}$ for the TOCSY spectra recorded on the 1.3-mM peptide sample in $10 \mathrm{mM} \mathrm{Na} \mathrm{CH}{ }_{3} \mathrm{COOH}(\mathrm{pH} 5), 150 \mathrm{mM} \mathrm{KCl}$ and in $10 \mathrm{mM}$ Tris- $\mathrm{HCl}$ (pH 7.4), $150 \mathrm{mM} \mathrm{KCl}$, and 100 and $300 \mathrm{~ms}$ for the NOESYs and $50 \mathrm{~ms}$ for the TOCSY spectra recorded on the 1-mM RNA sample in $10 \mathrm{mM}$ Tris- $\mathrm{HCl}$ (pH 7.4 and $\mathrm{pH} 5)$ and in $150 \mathrm{mM}$ salt $(\mathrm{KCl} / \mathrm{LiCl})$. Protein:RNA complex formation was studied by titrating a $0.3-\mathrm{mM}$ sample of RGG_P against RNA oligo in $10 \mathrm{mM}$ Tris- $\mathrm{HCl}(\mathrm{pH} 7.4)$ and $150 \mathrm{mM}$ salt $(\mathrm{KCl} / \mathrm{LiCl})$. The experiments described above were recorded in a $90 \% \mathrm{H}_{2} \mathrm{O} / 10 \%$ $\mathrm{D}_{2} \mathrm{O}$ mixture and water suppression was achieved by the WATERGATE pulse-sequence (Piotto et al. 1992; Sklenar et al. 1993).

The cross-saturation transfer experiments were recorded as described by Ramos et al. (2000a). Two separate difference experiments were recorded, at $27^{\circ} \mathrm{C}$ and $600 \mathrm{MHz}$ proton frequency, on the same 0.3-mM sample of RGG_P-SC1_RNA complex. Preirradiation was centered in the first experiment at $5.75 \mathrm{ppm}$ and in the second at $11.60 \mathrm{ppm}$ to saturate, respectively, the anomeric and imino regions of the RNA proton spectrum.

The spectra were processed and zero-filled to the next power of two using the NMRPIPE program (Delaglio et al. 1995). Baseline correction was applied when necessary. The spectral analysis was performed using the Felix (Accelerys) and XEASY programs (Bartels et al. 1995).

\section{ACKNOWLEDGMENTS}

We are indebted to Laura Masino for CD measurements and Andrew Lane and Salvatore Adinolfi for helpful discussions. We thank Jane Darnell for sharing with us unpublished results. The work was financed by a Human Frontier Grant (RGP0052/ 2001-B).

The publication costs of this article were defrayed in part by payment of page charges. This article must therefore be hereby marked "advertisement" in accordance with 18 USC section 1734 solely to indicate this fact.

Received May 30, 2003; accepted July 7, 2003.

\section{REFERENCES}

Adinolfi, S., Bagni, C., Musco, G., Gibson, T., Mazzarella, L., and Pastore, A. 1999. Dissecting FMR1, the protein responsible for fragile $\mathrm{X}$ syndrome, in its structural and functional domains. $R N A$ 5: $1248-1258$.

Adinolfi, S., Ramos, A., Martin, S.R., Dal Piaz, F., Pucci, P., Bardoni, B., Mandel, J.L., and Pastore, A. 2003. The N-terminus of the Fragile X Mental Retardation Protein contains a novel domain involved in dimerization and RNA-binding. Biochemistry (in press).

Bardoni, B. and Mandel, J.P. 2002. Advances in understanding of fragile $\mathrm{X}$ pathogenesis and FMRP function, and in identification of $\mathrm{X}$ linked mental retardation genes. Curr. Opin. Genet. Devel. 12: 284-293.

Bartels, C., Xia, T.H., Billeter, M., Gunter, P., and Wüthrich, K. 1995. The program XEASY for computer supported NMR spectral analysis of biological macromolecules. J. Biomol. NMR 5: 1-10.

Brown, V., Jin, P., Ceman, S., Darnell, J.C., O’Donnell, W.T., Tenenbaum, S.A., Jin, X., Feng, Y., Wilkinson, K.D., Keene, J.D., et al. 2001. Microarray identification of FMRP-associated brain mRNAs and altered mRNA translational profiles in Fragile X Syndrome. Cell 107: 477-487.

Buckanovich, R.J. and Darnell, R.B. 1997. The neuronal RNA binding protein Nova-1 recognizes specific RNA targets in vitro and in vivo. Mol. Cell. Biol. 17: 3194-3201.

Ceman, S., Brown, V., and Warren, S.T. 1999. Isolation of an FMRP associated messenger ribonucleoprotein particle and identification of nucleolin and the fragile X-related protein as components of the complex. Mol. Cell. Biol. 19: 7925-7932.

Ceman, S., Nelson, R., and Warren, S.T. 2000. Identification of mouse $\mathrm{YB} 1 / \mathrm{p} 50$ as a component of the FMRP-associated mRNP particle. Biochem. Biophys. Res. Commun. 279: 904-908.

Corbin, F., Bouillon, M., Fortin, A., Morin, S., Rousseau, F., and Khandjian, E.W. 1997. The fragile X mental retardation protein is associated with poly $(\mathrm{A})+\mathrm{mRNA}$ in actively translating polyribosomes. Hum. Mol. Genet. 6: 1465-1472.

Darnell, J.C., Jensen, K.B., Jin, P., Brown, V., Warren, S.T., and Darnell, R.B. 2001. Fragile X Mental Retardation protein targets G quartet mRNAs important for neuronal function. Cell 107: 489499.

De Diego Otero, Y., Severijnen, L.-A., van Cappellen, G., Schrier, M., Oostra, B., and Willemsen, R. 2002. Transport of Fragile X Mental Retardation protein via granules in neurites of PC12 cells. Mol. Cell. Biol. 22: 8332-8341.

Delaglio, F., Grzesiek, S., Vuister, G.V., Zhu, G., Pfeifer, J., and Bax, A. 1995. NMRPipe: A multidimensional spectral processing system based on UNIX pipes. J. Biomol. NMR 6: 277-293.

Feng, Y., Absher, D., Eberhart, D.E., Brown, V., Malter, H.E., and Warren, S.T. 1997. FMRP associates with polyribosomes as an mRNP, and the I304N mutation of severe fragile $\mathrm{X}$ syndrome abolishes this association. Mol. Cell 1: 109-118.

Ferrandon, D., Koch, I., Westhof, E., and Nusslein Volhard, C. 1997. 
RNA-RNA interaction is required for the formation of specific bicoid mRNA 3' UTR-STAUFEN ribonucleoprotein particles. EMBO J. 16: 1751-1758.

Hardin, C.C., Perry, A.G., and White, K. 2001. Thermodynamic and kinetic characterization of the dissociation and assembly of quadruplex nucleic acids. Biopolymers 56: 147-194.

Ishizuka, A., Siomi, M.C., and Siomi, H. 2002. A Drosophila fragile X protein interacts with components of RNAi and ribosomal proteins. Genes \& Dev. 16: 2497-2508.

Keniry, M.A. 2001. Quadruplex structures in nucleic acids. Biopolymers 56: 123-146.

Laggerbauer, B., Ostareck, D., Keidel, E.M., Ostareck-Lederer, A., and Fischer, U. 2001. Evidence that fragile X mental retardation protein is a negative regulator of translation. Hum. Mol. Genet. 10: 329338.

Li, Z., Zhang, Y., Ku, L., Wilkinson, K.D., Warren, S.T., and Feng, Y. 2001. The fragile $X$ mental retardation protein inhibits translation via interacting with mRNA. Nucleic Acids Res. 29: 2276-2283.

Mazroui, R., Huot, M.E., Tremblay, S., Filion, C., Label, Y., and Khandjian, E.W. 2002. Trapping of messenger mRNA by Fragile X Mental Retardation protein into cytoplasmatic granules induces translational repression. Hum. Mol. Genet. 11: 3007-3017.

Miyashiro, K.Y., Beckel-Mitchener, A., Purk, T.P., Becker, K.G., Barret, T., Liu, L., Carbonetto, S., Weiler, I.J., Greenough, W.T., and Eberwine J. 2003. RNA cargoes associating with FMR1 reveal deficits in cellular functioning in FMRP null mice. Neuron 37: 417431.

Müller, R., Kindler, S., and Garner, C.C. 1994. The MAP1 family. In Microtubules (eds. J.S. Hyams and C.W. Loyd), pp. 141-154. Wyley-Liss, New York.

Ohashi, S., Koike, K., Omori, A., Ichinose, S., Ohara, S., Kobayashi, S., Sato, T.A., and Anzai, K. 2002. Identification of mRNA/protein (mRNP) complexes containing Puralpha, mStaufen, fragile $\mathrm{X}$ protein, and myosine $\mathrm{Va}$ and their association with rough endoplasmatic reticulum equipped with a kinesin motor. J. Biol. Chem. 277: 37804-37810.
Piotto, M., Saudek, V., and Sklenar, V. 1992. Gradient-tailored excitation for single-quantum NMR spectroscopy of aqueus solutions. J. Biomol. NMR 2: 661-665.

Price, S.R., Ito, N., Oubridge, C., Avis, J.M., and Nagai, K. 1995. Crystallization of RNA-protein complexes. I. Methods for the large scale preparation of RNA suitable for crystallographic studies. $J$. Mol. Biol. 249: 398-408.

Ramos, A., Kelly, G., Hollingworth, D., Pastore, A., and Frenkiel, T. 2000a. Mapping the interfaces of protein-nucleic acid complexes using cross-saturation. J. Am. Chem. Soc. 122: 11311-11314.

Ramos, A., Grunert, S., Adams, J., Micklem, D.R., Proctor, M.R., Freund, S., Bycroft, M., St. Johnston, D., and Varani, G. 2000b. RNA recognition by a Staufen double stranded RNA binding domains. EMBO J. 19: 997-1009.

Schaeffer, C., Bardoni, B., Mandel, J.L., Ehresmann, B., Ehresmann, C., and Moine, H. 2001. The Fragile X Mental Retardation protein binds specifically to its mRNA via a purine quartet motif. EMBO J. 20: $4803-4813$.

Siomi, M.C., Zhang, Y., Siomi, H., and Dreyfuss, G. 1996. Specific sequences in the fragile $\mathrm{X}$ syndrome protein FMR1 and the FXR proteins mediate their binding to $60 \mathrm{~S}$ ribosomal subunits and the interactions among them. Mol. Cell. Biol. 16: 3825-3832.

Sklenar, V., Peterson, R.D., Rejante, M.R., and Feigon, J. 1993. Two and three dimensional $\mathrm{HCN}$ experiments for correlating base and sugar resonances in ${ }^{15} \mathrm{~N},{ }^{13} \mathrm{C}$ labelled RNA oligonucleotides. $J$. Biomol. NMR 3: 721-727.

Zalfa, F., Goirgi, M., Primerano, B., Moro, A., Di Penta, A., Reis, S., Oostra, B., and Bagni, C. 2003. The Fragile X Syndrome protein FMRP associates with BC1 RNA and regulates the translation of specific mRNAs at synapses. Cell 112: 317-327.

Zhang, Y.Q., Bailey, A.M., Matthies, H.J., Renden, R.B., Smith, M.A., Speese, S.D., Rubin, G.M., and Broadie, K. 2001. Drosophila fragile $\mathrm{X}$-related gene regulates the MAP1B homolog Futsch to control synaptic structure and function. Cell 107: 591-603.

Zuker, M. 2003. Mfold web server for nucleic acid folding and hybridization prediction. Nucleic Acids Res. 31: 1-10. 

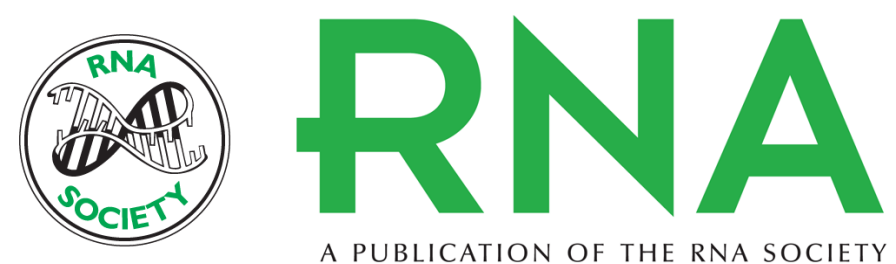

A PUBLICATION OF THE RNA SOCIETY

\section{G-quartet-dependent recognition between the FMRP RGG box and RNA}

ANDRES RAMOS, DAVID HOLLINGWORTH and ANNALISA PASTORE

RNA 2003 9: 1198-1207

References This article cites 29 articles, 10 of which can be accessed free at: http://rnajournal.cshlp.org/content/9/10/1198.full.html\#ref-list-1

\section{License}

Email Alerting Receive free email alerts when new articles cite this article - sign up in the box at the Service top right corner of the article or click here.

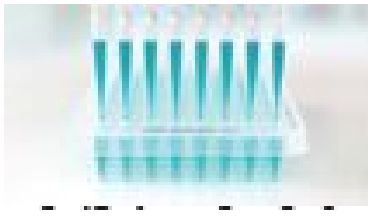

